\title{
ANALISIS PERENCANAAN BAHAN BAKU DI UD. AA DENGAN MENERAPKAN METODE MATERIAL REQUIREMENT PLANNING (MRP)
}

\author{
Rudi Abdika Saputra ${ }^{1}$, Inna Kholidasari ${ }^{2}$, Susanti Sundari ${ }^{3}$, Lestari Setiawati ${ }^{4}$ \\ ${ }^{1,2,4}$ Universitas Bung Hatta, Padang \\ ${ }^{3}$ Universitas Tulang Bawang, Lampung \\ Email :i.kholidasari@bunghatta.ac.id
}

\begin{tabular}{|c|c|}
\hline ARTICLE INFO & ABSTRACT \\
\hline $\begin{array}{l}\text { Keywords : } \\
\text { Economic Order } \\
\text { Quantity; Furniture; } \\
\text { Lot for Lot; Material } \\
\text { Requirement Planning; } \\
\text { Period Order Quantity }\end{array}$ & $\begin{array}{l}\text { This study discusses the application of the material requirements planning } \\
\text { (MRP) method in the planning of raw materials in a furniture company. The } \\
\text { purpose of this research is to know the planning of raw materials for furniture } \\
\text { products in UD. AA, determine the most suitable inventory model to be applied } \\
\text { to material inventory planning and analyze the role of the MRP system in ran } \\
\text { material procurement planning. The forecasting method used is the quantitative } \\
\text { method of time series analysis, determining the master production schedule, } \\
\text { calculating lot sizing (LFL, EOQ, POQ methods). From determining the Master } \\
\text { Production Schedule, it is found that the cabinet production plan for the next } \\
\text { three months is } 4 \text { units per period or week, and based on the calculation of } \\
\text { Material Requirement Planning (MRP) it can be seen what components are } \\
\text { needed for the manufacture of cabinets, how many and when each component is } \\
\text { required. Therefore it is obtained that the total raw material requirement for } \\
\text { wood for the next three months is } 11.34 \mathrm{~m}^{3} \text {. }\end{array}$ \\
\hline
\end{tabular}

\section{PENDAHULUAN}

Dalam menjaga persediaan bahan baku yang cukup agar kegiatan operasional perusahaan tidak terhenti, perlunya adanya pengawasan atau pengendalian persediaan. Kegiatan ini hanya mengurangi dan tidak akan dapat melenyapkan sama sekali risiko yang timbul akibat adanya persediaan yang terlalu besar atau terlalu kecil, hanya dapat membantu mengurangi risiko menjadi sekecil mungkin.

UD. AA adalah sebuah industri kecil yang bergerak di bidang furniture perabot rumah tangga yang menggunakan kayu sebagai bahan baku utama. jenis produk yang dihasilkan seperti lemari, tempat tidur, kursi, dan meja. UD. AA selama ini hanya melakukan pembelian bahan baku berdasarkan pembelian-pembelian yang sebelumnya yaitu 2 sampai 3 kali dalam seminggu ketika persediaan di gudang sudah hampir habis. Dengan cara tersebut, kelebihan ataupun kekurangan stok bahan baku masih sering terjadi yang dapat menyebabkan terhambatnya proses produksi dan membengkaknya biaya. Sistem produksi yang digunakan oleh perusahaan ini adalah make to order yaitu mengerjakan produksi furniture apabila ada pemesanan dari konsumen, sehingga kelancaran proses produksi sangat dipengaruhi oleh ketersediaan stok material. Dari masalah yang sering ditemukan ini, diperlukan suatu sistem pengendalian persediaan yang tepat dan dapat menentukan biaya persediaannya seoptimal mungkin melalui penerapan MRP dengan beberapa teknik lot sizing yang digunakan yaitu dengan metode Economic Order Quantity (EOQ), Lot for Lot (LFL), dan Period Order Quantity (POQ). Ketiga model ini diambil karena sesuai dengan kondisi dan data yang terdapat pada UD. AA yang bersifat probabilistik dinamik. Dari ketiga metode yang diterapkan dapat dianalisa metode terbaik untuk kasus pada UD. AA. Tujuan dari penelitian ini dilakukan adalah untuk menentukan model persediaan yang paling sesuai untuk diterapkan pada perencanaan persediaan material, mengetahui perencanaan kebutuhan material pada produk furniture di UD. AA, dan menganalisa perencanaan pengadaan bahan baku dengan metode MRP. 


\section{KAJIAN LITERATUR}

\section{Pengertian Bahan Baku}

Bahan baku adalah merupakan input dari proses transformasi dari produk jadi. untuk membedakan apakah bahan baku termasuk bahan penolong adalah dengan cara mengadakan penelusuran terhadap bahan-bahan atau elemen-elemen kedalam produk jadi. Cara pengadaan bahan baku bisa diperoleh dari sumber-sumber alam, misalnya serat diolah menjadi benang.. Bahan baku tidak bisa tersedia setiap saat, karenanya perusahaan perlu mengadakan persediaan bahan baku (Nasution, 2003)

\section{Peramalan (Forecasting)}

Peramalan permintaan akan produk dan jasa di waktu mendatang sangat penting dalam perencanaan dan pengawasan produksi dalam menyelesaikan masalah di masa datang yang tidak dapat dipastikan, orang senantiasa berupaya menyelesaikannya dengan model pendekatan-pendekatan yang sesuai dengan perilaku aktual data, begitu juga dalam melakukan peramalan. Selain untuk memperkirakan apa yang akan terjadi dimasa yang akan datang peramalan juga diperlukan bagi pengambil keputusan untuk membuat perencanaan. Peramalan adalah kegiatan memperkirakan tingkat permintaan produk yang diharapkan untuk suatu produk atau beberapa produk dalam periode waktu tertentu di masa yang akan datang. (John E. Biegel, 1999). Pe ramalan penjualan merupakan proses kegiatan memperkirakan produk yang akan dijual pada waktu yang akan datang dalam keadaan tertentu dan dibuat berdasarkan data yang pernah terjadi dan atau mungkin akan terjadi (Nafarin, 2000).

\section{Metode Perencanaan Kebutuhan Material (Material Requirement Planning)}

Menurut Senator Nur Bahagia, tiga masukan utama yang diperlukan dalam mekanisme kerja MRP, yaitu:

1) Jadwal Induk Produksi (JIP), adalah suatu rencana produksi yang menggambarkan hubungan antara jenis dan kuantitas setiap jenis produk akhir dengan waktu penyediaannya.

2) Status Inventory, yang menggambarkan keadaan setiap bahan atau komponen yang terdapat dalam sistem inventory. Sistem inventory dalam MRP berkaitan dengan informasi tentang:

a. Jumlah inventory yang ada digudang pada setiap periode (inventory on hand).

$b$. Jumlah barang yang sedang dipesan dan kapan pesanan tersebut datang (inventory on order).

c. Waktu ancang-ancang (lead time) setiap komponennya.

3). Struktur Produk, adalah kaitan antara produk dengan komponen-komponen penyusunnya mulai dari bahan baku sampai produk jadi. Kelengkapan informasi untuk setiap komponen ini meliputi: jenis komponen, jumlah yang dibutuhkan dan tingkat penyusunannya.

Tabel 1. Contoh Tabel MRP

\begin{tabular}{|c|c|c|c|c|c|c|c|c|c|c|c|c|}
\hline $\begin{array}{l}\text { Part No: } \\
\text { Lot Sizing: }\end{array}$ & $\begin{array}{l}\text { Lea } \\
\text { Use } \\
\text { Safe }\end{array}$ & Sto & & & & & & & & & & Time: \\
\hline Periode & 1 & 2 & 3 & 4 & 5 & 6 & 7 & 8 & 9 & 10 & 11 & 12 \\
\hline $\begin{array}{c}\text { Gross } \\
\text { Requirement }\end{array}$ & & & & & & & & & & & & \\
\hline $\begin{array}{l}\text { Scheduled } \\
\text { Receipt }\end{array}$ & & & & & & & & & & & & \\
\hline $\begin{array}{l}\text { Project On } \\
\text { Hand }\end{array}$ & & & & & & & & & & & & \\
\hline $\begin{array}{c}\text { Net } \\
\text { Requirement }\end{array}$ & & & & & & & & & & & & \\
\hline $\begin{array}{c}\text { Planned Order } \\
\text { Receipt }\end{array}$ & & & & & & & & & & & & \\
\hline $\begin{array}{c}\text { Planned Order } \\
\text { Release }\end{array}$ & & & & & & & & & & & & \\
\hline
\end{tabular}




\section{Teknik Lot Sizing dalam MRP}

Ukuran jumlah barang yang dipesan (lot size) akan berhubungan dengan biaya pemesanan (set up) dan biaya penyimpanan barang, semakin rendah ukuran lot berarti semakin sering melakukan pemesanan barang, akan menurunkan biaya penyimpanan, tetapi menambah biaya pemesanan barang. Sebaliknya semakin tinggi ukuran lot akan mengurangi frekuensi pemesanan, berarti mengurangi biaya pemesanan tetapi meningkatkan biaya penyimpanan. Untuk itu perlu dicari ukuran lot yang tepat agar dapat meminimalkan total biaya persediaan, dan menurut Zulian Yamit (1998) penjelasannya adalah sebagai berikut:

\section{1) Lot for lot (LFL)}

Metode ini dikenal sebagai metode persediaan minimal, yaitu jumlah persediaan diusahakan seminimal mungkin untuk memproduksi sesuai dengan yang diperlukan saja. Sehingga biaya yang timbul berupa biaya pemesanan saja. Metode ini beresiko tinggi jika terjadi keterlambatan dalam pengiriman barang, maka dapat mengakibatkan terhentinya produksi.

2) Economic Order Quantity (EOQ)

Model persediaan Economic Order Quantity (EOQ) merupakan salah satu model yang diperkenalkan oleh FW Harris pada tahun 1914, tetapi paling banyak dikenal dalam teknik pengendalian persediaan. Metode ini banyak dipakai sampai saat ini karena mudah dalam penggunaannya, meskipun dalam penerapannya harus memperhatikan asumsi yang dipakai. Adapun rumus perhitungan EOQ adalah:

$\mathrm{EOQ}=\sqrt{2} \mathrm{SD} / \mathrm{H}$

Dimana:

EOQ: yaitu kuantitas pembelian optimal

S: Biaya pemesanan

D: Ialah penggunaan bahan baku pertahun

$\mathrm{H}$ : Biaya penyimpanan per-unit

\section{3) Period Order Quantity (POQ)}

Metode POQ pada dasarnya adalah pemesanan barang menurut suatu sistem interval pesan (T) yang tetap dengan jumlah ukuran lot pemesanan sama dengan kebutuhan barang selama periode pemesanan yang dicakup. Adapun rumus dari POQ adalah:

$$
P O Q=\frac{1}{\bar{D}} \sqrt{\frac{2 P D}{S}}
$$

Dimana:

POQ: ialah Frekuensi Pemesanan

P: Biaya Pemesanan setiap kali pesan

$\bar{D}$ : Permintaan rata-rata waktu horizon perencanaan

D: permintaan rata-rata per produksi

S: Biaya simpan bahan baku

\section{METODE PENELITIAN}

\section{Penelitian Pendahuluan}

Penelitian pendahuluan dilakukan untuk mengenal perusahaan secara keseluruhan dan mengetahui masalah-masalah yang dihadapi oleh perusahaan untuk diangkat menjadi objek penelitian. Selanjutnya dilakukan survey dan observasi ke perusahaan agar memperoleh pemecahan masalah yang tepat di UD. AA.

\section{Studi Literatur}

Sebagai penunjang penelitian diuraikan teori-teori yang berkaitan dengan masalah maka dilakukan studi kepustakaan, referensi didapatkan melalui jurnal-jurnal penelitian sebelumnya, tulisan-tulisan ilmiah, dan buku-buku yang berkaitan dengan manajemen persediaan. 


\section{Identifikasi \& Rumusan Masalah}

Mengidentifikasi masalah akan membantu memperjelas sesuatu yang ingin dicapai pada penelitian ini, apabila permasalahan sudah diketahui selanjutnya dibuat suatu rumusan masalah. Pada penelitian ini, masalah yang dihadapi perusahaan adalah ketidakmampuan perusahaan dalam menyediakan bahan baku dalam jumlah dan waktu yang tepat.

\section{Pengumpulan Data}

Dalam penelitian ini data yang dibutuhkan antara lain sebagai berikut:

a. Data pemesanan produk lemari selama satu tahun.

b. Data struktur produk lemari

c. Data persediaan komponen lemari.

d. Data waktu ancang (lead time) setiap komponen pembentuk lemari.

e. Data onkos-ongkos persediaan untuk produk lemari.

\section{Pengolahan Data}

\section{a. Tahap Peramalan}

Tahapan ini bertujuan untuk memperkirakan kebutuhan bahan baku masa yang akan datang. Pengumpulan data-data peramalan didapat dari data pemesanan produk lemari selama satu tahun. Ada banyak macam metode peramalan yang telah dikembangkan, maka perlu ditentukan metode peramalan yang cocok untuk pola permintaan kayu untuk produk lemari. Yang diharapkan dari penerapan metode peramalan ini adalah dapat mengurangi sedikit ketidakpastian dimasa yang akan datang. Model peramalan yang digunakan adalah model peramalan secara kuantitatif dengan melihat pola data, yaitu metode Exsponential Smoothing untuk memastikan hasil peramalan motode Exsponential Smoothing yang akan digunakan maka dilakukan pengukuran ketelitian dengan menggunakan indikator Mean Absolute Deviation (MAD) terkecil untuk setiap kebutuhan barang dengan bantuan Software POM For Windows program Forcasting.

b. Tahap Penentuan Jadwal Induk Produksi, yang merupakan jumlah rincian produk akhir berdasarkan hasil induk produksi untuk tiga bulan yang akan datang.

c. Tahap Perhitungan Material Requirement Planning (MRP)

Berdasarkan perhitungan Jadwal Induk Produksi, maka perencanaan kebutuhan bahan dapat dilakukan. Berikut adalah data-data yang akan diolah dalam MRP yaitu:

a) Master Production Schedules

Master Production Schedules (MPS) mewakili sebuah rencana untuk pelaksanaan produksi. MPS dibuat berdasarkan hasil forecasting dan pesanan konsumen. Karena produksi di UD. AA adalah make to order, maka MPS yang dibuat hanya berdasarkan forecasting saja. Dari MPS tersebut ditampilkan dalam bentuk bulanan (tergantung pemakaian) untuk memudahkan perhitungan dan pelaksanaannya.

b) Status persediaan

c) Struktur produk atau (Bill of Material/BOM).

d. Perhitungan Lot Sizing

Ukuran lot dihitung secara manual dan dibantu dengan menggunakan metode-metode berikut:

a) Lot for Lot (LFL)

b) Economic Order Quantity (EOQ)

c) Period Order Quantity (POQ)

\section{Analisis Hasil Pengolahan Data}

Setelah semua langkah pengumpulan dan pengolahan data dilakukan, selanjutnya dianalisis model persediaan yang paling sesuai untuk UD. AA dan memberi suatu usulan atau strategi yang nantinya akan menjadi masukan dan acuan bagi perusahaan. 


\section{HASIL DAN PEMBAHASAN}

\section{Data Pemesanan Produk Lemari}

Dari hasil wawancara dengan pemilik UD. AA dapat diketahui bahwa produk yang paling banyak diproduksi adalah Lemari. Atas dasar itu maka penelitian ini mengambil produk Lemari sebagai objek penelitian. Bahan baku yang digunakan pada produk Lemari adalah kayu dan triplek. Data pada bulan Maret 2018 sampai dengan Februari 2019 adalah data permintaan yang digunakan selama satu tahun. Pada tabel 2. dapat dilihat data pemesanan produk Lemari.

Tabel 2. Data Pemesanan Produk Lemari

\begin{tabular}{cccc}
\hline $\begin{array}{c}\text { No } \\
\cdot\end{array}$ & T ahun & Bulan & Pemesanan \\
\hline 1 & & & \\
\hline 2 & 2018 & Maret & 16 \\
\hline 3 & 2018 & April & 18 \\
\hline 4 & 2018 & Mei & 9 \\
\hline 5 & 2018 & Juni & 10 \\
\hline 6 & 2018 & Juli & 19 \\
\hline 7 & 2018 & September & 16 \\
\hline 8 & 2018 & Oktober & 8 \\
\hline 9 & 2018 & November & 17 \\
\hline 10 & 2018 & Desember & 22 \\
\hline 11 & 2019 & Januari & 13 \\
\hline 12 & 2019 & Februari & 15 \\
\hline Sumber: Pengumpulan Data UDAA, 2019
\end{tabular}

Dari data pada tabel 2 dapat diketahui bahwa pemesanan produk lemari terjadi secara acak, jumlah permintaan pemesanan selama satu tahun dari Maret 2018 sampai Februari 2019 adalah berjumlah 177 unit lemari.

\section{Struktur Produk}

Komponen-komponen penyusun Lemari dapat dilihat pada gambar. 2.

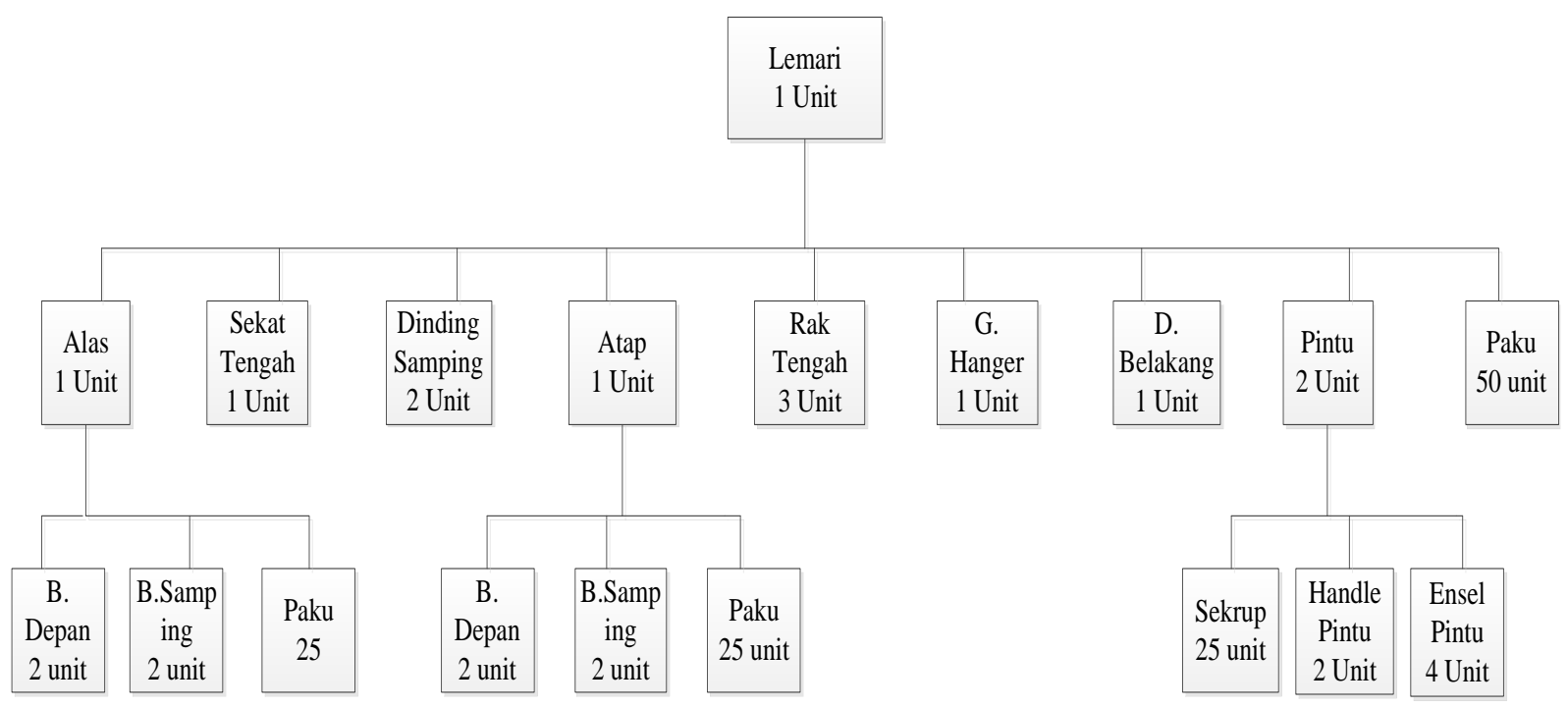

Gambar 2. Struktur Produk Lemari 


\section{Persediaan bahan baku dan Lead Time Komponen Lemari}

Pada tabel 3, lead time untuk masing-masing komponen dihitung mulai dari pemesanan sampai bahan baku tiba ditambah dengan lamanya waktu proses pengerjaan sampai komponen siap dipakai.

Tabel 3. Data Persediaan dan Waktu Ancang Komponen Lemari

\begin{tabular}{cccc}
\hline No & Nama Komponen & Persediaan & $\begin{array}{c}\text { Lead Time } \\
\text { (Minggu) }\end{array}$ \\
\hline 1 & Lemari & 2 & 1 \\
\hline 2 & Alas & 0 & 1 \\
\hline 3 & Bingkai Depan Alas & 10 & 1 \\
\hline 4 & Bingkai Samping Alas & 10 & 1 \\
\hline 5 & Atap & 0 & 1 \\
\hline 6 & Sekat T engah & 7 & 1 \\
\hline 6 & Bingkai Depan Atap & 12 & 1 \\
\hline 7 & Bingkai Samping Atap & 12 & 1 \\
\hline 8 & Dinding Samping & 0 & 1 \\
\hline 9 & Rak & 8 & 1 \\
\hline 10 & Gantungan Hanger & 10 & 1 \\
\hline 11 & Dinding Belakang & 0 & 1 \\
\hline 12 & Pintu & 8 & 1 \\
\hline 13 & Ensel Pintu & 40 & 1 \\
\hline 14 & Handle Pintu & 30 & 1 \\
\hline 15 & Paku & 200 & 1 \\
\hline 16 & Sekrup & 50 & 1 \\
\hline Sumber: Pengumpulan Data UD.AA, 2019 & & \\
\hline
\end{tabular}

\section{Biaya Pemesanan}

Dari hasil wawancara yang telah dilakukan, didapatkan bahwa biaya pemesanan untuk bahan baku pada UD.AA sudah termasuk ke dalam biaya transportasi, administrasi dan biaya bongkar muat. Tabel 4. menyajikan data biaya pesan untuk satu kali pemesanan.

Tabel 4. Daftar Biaya Pemesanan Bahan Baku L emari

\begin{tabular}{ccc}
\hline No & Bahan Baku & Biaya \\
\hline 1 & Kayu Jenis Bayur & Rp. 400.000 \\
\hline 2 & Triplek & Rp. 12.500 \\
\hline 3 & Ensel Pintu & Rp. 12.500 \\
\hline 4 & Handle Pintu & Rp. 12.500 \\
\hline 5 & Sekrup & Rp. 12.500 \\
\hline & Jumlah & Rp. 450.000 \\
\hline
\end{tabular}

Sumber: Pengumpulan Data UD.AA, 2019

UD. AA melakukan pemesanan sebanyak $6 \mathrm{~m}^{3}$ kayu untuk satu kali pemesanan, untuk satu lemari membutuhkan kayu sebanyak $135.000 \mathrm{~cm}^{3}$. Untuk menentukan biaya pesan dalam 1 unit lemari diketahui sebagai berikut : 1 unit lemari $=135.000 \mathrm{~cm}^{3} ; 6 \mathrm{~m}^{3} \mathrm{kayu}=40$ lemari.

Ongkos pesan / 40 unit lemari $=$ Rp.450.000 / $40=$ Rp.11.250 dibulatkan Rp. 11.000. Jadi untuk satu unit lemari membutuhkan biaya pesan Rp. 11.000.

\section{Biaya Penyimpanan (Holding Cost)}

Biaya penyimpanan pada UD. AA terdiri dari biaya sewa gudang dan upah petugas jaga. Berikut uraian biaya penyimpanan bahan baku:

a. Sewa tempat gudang bahan baku seluas $150 \mathrm{~m} 2$ adalah Rp. 5.000 .000 per tahun.

b. Upah penjaga gudang 1 orang adalah Rp. 12.000 .000 per tahun.

Jadi Total biaya adalah Rp. 17.000.000 per tahun. 
Dilihat dari kapasitas gudang yang mampu menampung $20 \mathrm{~m}^{3}$ maka biaya penyimpanan bahan baku per tahun untuk biaya penyimpanan per kubik adalah biaya penyimpanan gudang dibagi dengan kapasitas gudang, maka hasil yang didapat adalah Rp. 850.000 per tahun. Dikonversikan menjadi perminggu yaitu Rp.18.000.

\section{Pengolahahan Data}

a. Tahap Peramalan

Program yang digunakan dalam menentukan hasil peramalan adalah program POM for Windows 3 didasarkan pada nilai MAD yang terkecil.

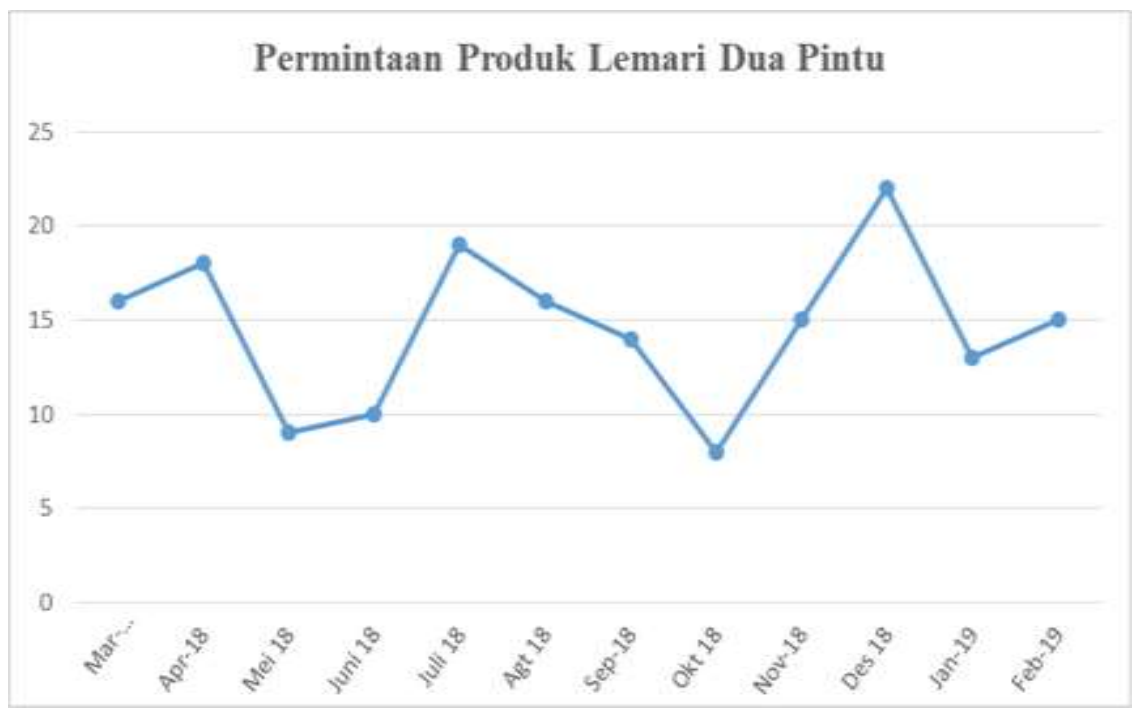

Gambar 3. Grafik Permintaan Produk Lemari

Hasil peramalan permintaan dengan POM for Windows 3 menunjukkan bahwa hasil peramalan permintaan dengan metode Exponential Smoothing lebih baik daripada metode Moving Average, karena memiliki MAD, MAPE, dan MSE yang lebih kecil.

b. Tahap Penentuan Jadwal Induk Produksi (JIP)

Ini merupakan rincian produk akhir berdasarkan hasil induk produksi untuk 3 bulan yang akan datang yaitu pada bulan Maret, April dan Mei 2019, dan periode produksi dalam mingguan. Sehingga diperoleh jadwal induk produksi untuk tiga bulan yang akan datang adalah sebagai berikut:

$$
\text { JIP : } \frac{16,33}{4}=4,08 \approx 4 \text { unit/minggu }
$$

Tabel 5. Jadwal Induk Produksi Komponen Untuk Tiga Bulan Yang Akan Datang

\begin{tabular}{|c|c|c|c|c|c|c|c|c|c|c|c|c|c|c|c|c|c|}
\hline \multirow[b]{2}{*}{ No } & \multirow[b]{2}{*}{ Minggu } & \multirow[b]{2}{*}{ Bulan } & \multicolumn{15}{|c|}{ Keb uthan Barang Per Komponen } \\
\hline & & & Alas & $\begin{array}{c}\text { Sekat } \\
\text { Tengah }\end{array}$ & Atap & $\begin{array}{l}\text { Dinding } \\
\text { Sampig }\end{array}$ & Rak & $\begin{array}{c}\text { G. } \\
\text { Hanger }\end{array}$ & $\begin{array}{c}\text { D.Beka } \\
\text { kang }\end{array}$ & Pintu & $\begin{array}{l}\text { Ensel } \\
\text { pintu }\end{array}$ & $\begin{array}{c}\text { Handle } \\
\text { p intu }\end{array}$ & Sekrup & $\begin{array}{l}\text { B.Depa } \\
\text { n Alas }\end{array}$ & $\begin{array}{c}\text { B. } \\
\text { Sampi } \\
\text { ng } \\
\text { Alas }\end{array}$ & $\begin{array}{c}\text { B. } \\
\text { Depan } \\
\text { Atap }\end{array}$ & $\begin{array}{c}\text { B. } \\
\text { Sampi } \\
\text { ng } \\
\text { Atap }\end{array}$ \\
\hline $\mathbf{l}$ & $\mathbf{l}$ & Maret & 4 & 4 & 4 & 8 & 12 & 4 & 4 & 8 & 16 & 8 & 200 & 8 & 8 & 8 & 8 \\
\hline 2 & 2 & Maret & 4 & 4 & 4 & 8 & 12 & 4 & 4 & 8 & 16 & 8 & 200 & 8 & 8 & 8 & 8 \\
\hline 3 & 3 & Maret & 4 & 4 & 4 & 8 & 12 & 4 & 4 & 8 & 16 & 8 & 200 & 8 & 8 & 8 & 8 \\
\hline 4 & 4 & Maret & 4 & 4 & 4 & 8 & 12 & 4 & 4 & 8 & 16 & 8 & 200 & 8 & 8 & 8 & 8 \\
\hline 5 & 5 & April & 4 & 4 & 4 & 8 & 12 & 4 & 4 & 8 & 16 & 8 & 200 & 8 & 8 & 8 & 8 \\
\hline 6 & 6 & April & 4 & 4 & 4 & 8 & 12 & 4 & 4 & 8 & 16 & 8 & 200 & 8 & 8 & 8 & 8 \\
\hline 7 & 7 & April & 4 & 4 & 4 & 8 & 12 & 4 & 4 & 8 & 16 & 8 & 200 & 8 & 8 & 8 & 8 \\
\hline 8 & 8 & April & 4 & 4 & 4 & 8 & 12 & 4 & 4 & 8 & 16 & 8 & 200 & 8 & 8 & 8 & 8 \\
\hline 9 & 9 & Mei & 4 & 4 & 4 & 8 & 12 & 4 & 4 & 8 & 16 & 8 & 200 & 8 & 8 & 8 & 8 \\
\hline 10 & 10 & Mei & 4 & 4 & 4 & 8 & 12 & 4 & 4 & 8 & 16 & 8 & 200 & 8 & 8 & 8 & 8 \\
\hline 11 & 11 & Mei & 4 & 4 & 4 & 8 & 12 & 4 & 4 & 8 & 16 & 8 & 200 & 8 & 8 & 8 & 8 \\
\hline 12 & 12 & Mei & 4 & 4 & 4 & 8 & 12 & 4 & 4 & 8 & 16 & 8 & 200 & 8 & 8 & 8 & 8 \\
\hline
\end{tabular}


E-ISSN 2621-6442

c. Lot Sizing Material Requirement Planning (MRP)

Tahap Perhitungan Perencanaan Kebutuhan Bahan Dengan Metode Lot for Lot

1. Lemari

Tabel 6. MRP Lemari Dengan LFL

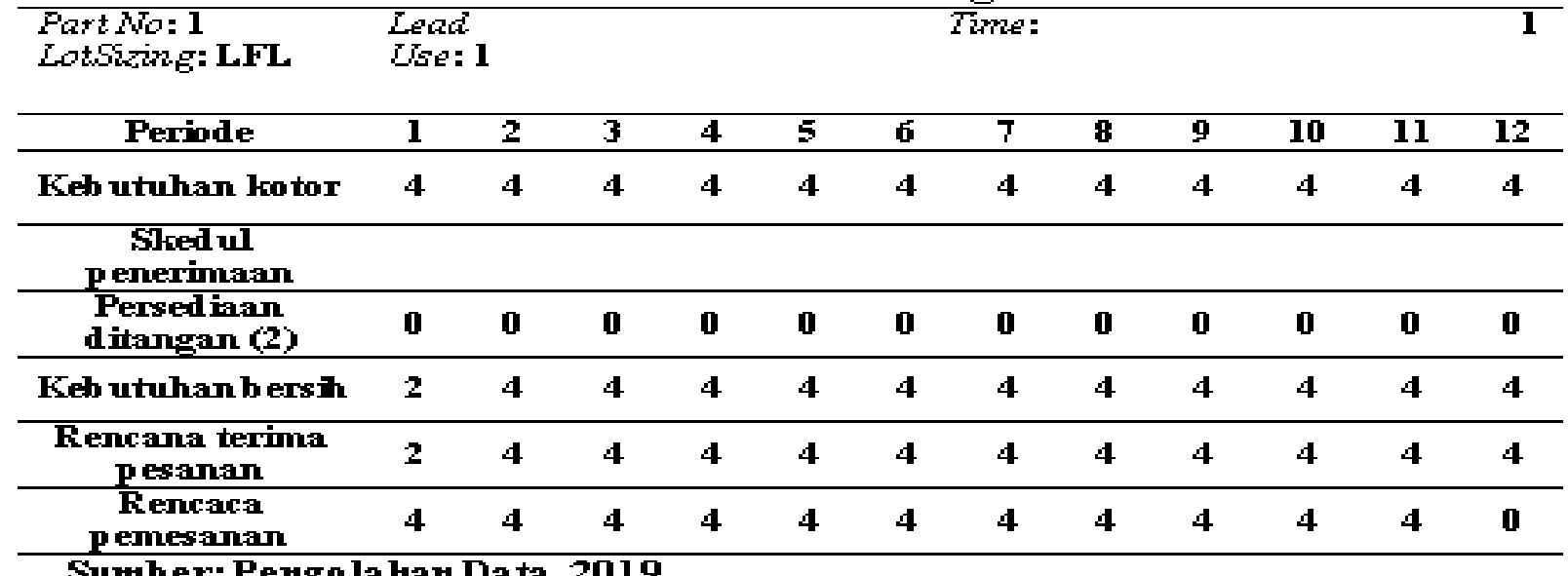

Sumber: Pergo laham Data, 2019

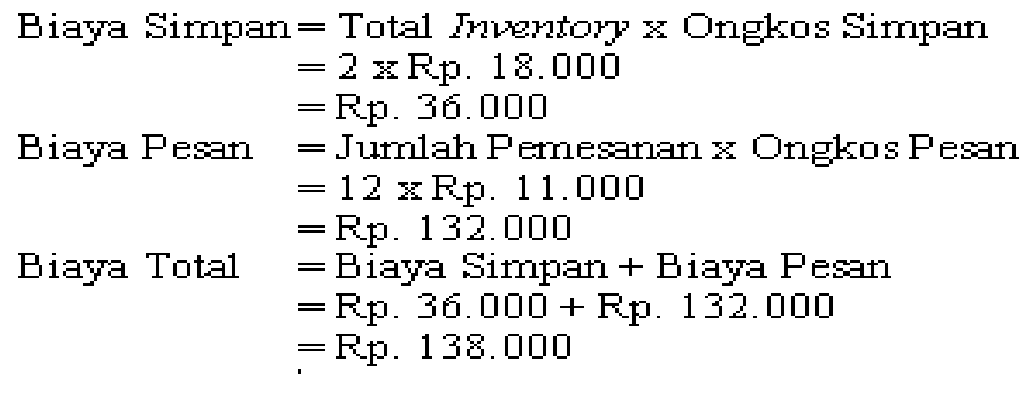

d. Metode Economic Order Quantity (EOQ)

$\mathrm{EOQ}=\sqrt{\frac{2 n D n \text { anghasperarl }}{\text { arghas simpari }}}$

1. Lemari

$D=(4+4+4+4+4+4+4+4+4+4+4+4) / 12$

$=4$

$\mathrm{EOQ}=\sqrt{\frac{2 \times 4 \times 1100]}{180[0}}=4,22 \mathrm{z}$

Ftelotetisi $=\frac{\operatorname{Demand}}{\operatorname{soQ}}=\frac{4}{2}=2$ 
Tabel S. MRP Lemari Dengan POQ

\begin{tabular}{|c|c|c|c|c|c|c|c|c|c|c|c|c|}
\hline $\begin{array}{l}\text { Part No: 1 } \\
\text { (Lemari) } \\
\text { LotSizing: } \\
\text { POQ }\end{array}$ & $\begin{array}{l}\text { Lead } \\
\text { Use: } 1\end{array}$ & & & & & & ne: & & & & & $\mathbf{1}$ \\
\hline Periode & 1 & 2 & 3 & 4 & 5 & 6 & 7 & 8 & 9 & 10 & 11 & 12 \\
\hline $\begin{array}{l}\text { Kebutuhan } \\
\text { Kootor }\end{array}$ & 4 & 4 & 4 & 4 & 4 & 4 & 4 & 4 & 4 & 4 & 4 & 4 \\
\hline $\begin{array}{c}\text { Skedul } \\
\text { penerimaan }\end{array}$ & & & & & & & & & & & & \\
\hline $\begin{array}{l}\text { Persediaan } \\
\text { ditangan (2) }\end{array}$ & $\mathbf{0}$ & & & & & & & & & & & \\
\hline $\begin{array}{c}\text { Keb utuhan } \\
\text { b ersih }\end{array}$ & & 4 & 4 & 4 & 4 & 4 & 4 & 4 & 4 & 4 & 4 & 4 \\
\hline $\begin{array}{c}\text { Rencana } \\
\text { terima } \\
\text { pesanan }\end{array}$ & & 4 & 4 & 4 & 4 & 4 & 4 & 4 & 4 & 4 & 4 & 4 \\
\hline $\begin{array}{c}\text { Rencaca } \\
\text { pemesanan }\end{array}$ & 4 & 4 & 4 & 4 & 4 & 4 & 4 & 4 & 4 & 4 & 4 & \\
\hline
\end{tabular}

Biaya Simpan = Total Inventory $\mathrm{x}$ Ongkos Simpan

$$
\begin{aligned}
& =2 \times \text { Rp. } 18.000 \\
& =\text { Rp. } 36.000
\end{aligned}
$$

Biaya Pesan = Jumlah Pemesanan $\mathrm{x}$ Ongkos Pesan

$=11 \times$ Rp. 11.000

$=$ Rp. 121.000

Biaya Total = Biaya Simpan + Biaya Pesan

$=$ Rp. $36.000+$ Rp. $121.000=$ Rp. 157.000

\begin{tabular}{|c|c|c|c|c|c|c|c|c|c|c|c|c|}
\hline $\begin{array}{l}\text { Part No: 1 } \\
\text { LotShzing: } \\
\text { EOQ }\end{array}$ & $\begin{array}{l}\text { Lea } \\
\text { Ust }\end{array}$ & me & & & & & & & & & & \\
\hline Periode & $\mathbf{l}$ & 2 & 3 & 4 & 5 & 6 & 7 & 8 & 9 & 10 & 11 & 12 \\
\hline $\begin{array}{l}\text { Keb utuhan } \\
\text { kotor }\end{array}$ & 4 & 4 & 4 & 4 & 4 & 4 & 4 & 4 & 4 & 4 & 4 & 4 \\
\hline $\begin{array}{c}\text { Skedul } \\
\text { p enerimaan }\end{array}$ & & & & & & & & & & & & \\
\hline $\begin{array}{c}\text { Persediaan } \\
\text { diiangan (2) }\end{array}$ & & 2 & & & & & & & & & & \\
\hline $\begin{array}{l}\text { Kebutuhan } \\
\text { bersih }\end{array}$ & & 2 & 4 & 4 & 4 & 4 & 4 & 4 & 4 & 4 & 4 & 4 \\
\hline $\begin{array}{c}\text { Rencana } \\
\text { terima } \\
\text { pesanan }\end{array}$ & & 4 & & & & & & & & & & \\
\hline $\begin{array}{c}\text { Rencaca } \\
\text { pemesanan }\end{array}$ & 4 & & & & & & & & & & & \\
\hline
\end{tabular}

Tabel 7. MRP Lemari Dengan EOQ

Biaya Simpan = Total Inventory $\mathrm{x}$ Ongkos Simpan

$=2 \times$ Rp. 18.000

$=$ Rp. 36.000

Biaya Pesan = Jumlah Pemesanan $\mathrm{x}$ Ongkos Pesan

$=1 \mathrm{x}$ Rp. 11.000

$=$ Rp. 11.000

Biaya Total = Biaya Simpan + Biaya Pesan

$=$ Rp. $36.000+$ Rp. $11.000=$ Rp. 47.000 
10

E-ISSN 2621-6442

e. Metode Period Order Quantity (POQ)

$\mathrm{POQ}=\mathrm{EOQ} / \mathrm{D}$

\section{Lemari}

$$
\begin{aligned}
& \mathrm{D}=(4+4+4+4+4+4+4+4+4+4+4+4) / 12=4 \\
& \mathrm{EOQ}=\sqrt{\frac{2 \times 4 \times 110][}{180[0]}}=3 \\
& \mathrm{POQ}=\frac{3}{4}=0,75=1
\end{aligned}
$$

Ringkasan perhitungan dari rencana untuk tiga bulan yang akan datang dalam kebutuhan komponen kayu

\begin{tabular}{|c|c|c|c|c|c|c|c|c|c|c|c|c|}
\hline \multirow{2}{*}{ No } & \multirow{2}{*}{ Komponen } & \multicolumn{10}{|c|}{ Minggu } & \multirow{2}{*}{$\begin{array}{l}\text { Total } \\
\left(\mathrm{cm}^{3}\right)\end{array}$} \\
\hline & & 1 & 2 & 3 & 4 & 5 & 6 & 7 & 8 & 9 & 10 & \\
\hline 1 & Alas & 242.000 & 242.000 & 242.000 & 242.000 & 242.000 & 242.000 & 242.000 & 242.000 & 242.000 & 242.000 & 2.242 .000 \\
\hline 2 & Bingkai Depan Alas & 36.000 & 48.000 & 48.000 & 48.000 & 48.000 & 48.000 & 48.000 & 48.000 & 48.000 & & 420.000 \\
\hline 3 & $\begin{array}{l}\text { Bingkai Samping } \\
\text { Alas }\end{array}$ & 36.000 & 48.000 & 48.000 & 48.000 & 48.000 & 48.000 & 48.000 & 48.000 & 48.000 & & 420.000 \\
\hline 4 & Sekat Tengah & 22.725 & 90.900 & 90.900 & 90.900 & 90.900 & 90.900 & 90.900 & 90.900 & 90.900 & 90.900 & 840.825 \\
\hline 5 & Atap & 242.000 & 242.000 & 242.000 & 242.000 & 242.000 & 242.000 & 242.000 & 242.000 & 242.000 & 242.000 & 2.242 .000 \\
\hline 6 & $\begin{array}{l}\text { Bingkai Depan } \\
\text { Atap }\end{array}$ & 36.000 & 48.000 & 48.000 & 48.000 & 48.000 & 48.000 & 48.000 & 48.000 & 48.000 & & 420.000 \\
\hline 7 & $\begin{array}{l}\text { Bingkai Samping } \\
\text { Atap }\end{array}$ & 36.000 & 48.000 & 48.000 & 48.000 & 48.000 & 48.000 & 48.000 & 48.000 & 48.000 & & 420.000 \\
\hline 8 & Dinding Samping & 181.000 & 181.000 & 181.000 & 181.000 & 181.000 & 181.000 & 181.000 & 181.000 & 181.000 & 181.000 & 1.810 .000 \\
\hline 9 & Rak & 25.000 & 75.000 & 75.000 & 75.000 & 75.000 & 75.000 & 75.000 & 75.000 & 75.000 & 75.000 & 700.000 \\
\hline 10 & Gantungan Hanger & & 375 & 400 & 400 & 400 & 400 & 400 & 400 & 400 & & 3.175 \\
\hline 11 & Pintu & 49.500 & 198.000 & 198.000 & 198.000 & 198.000 & 198.000 & 198.000 & 198.000 & 198.000 & 198.000 & 1.831 .000 \\
\hline
\end{tabular}
pembentuk lemari (dalam unit) setiap minggunya dapat dilihat pada tabel 9.

Tabel 9. Rekapitulasi Rencana Kebutuhan Bahan Baku Kayu Pembentuk Lemari Perkonponen (Dalam $\mathrm{cm}^{3}$ ) 
f. Penentuan Ukuran Lot Optimal

Tabel 10. Hasil Perhitungan Biaya Perkomponen Kedua Teknik (Dalam cm³)

\begin{tabular}{|c|c|c|c|c|}
\hline No & Komponen & LFL & EOQ & POQ \\
\hline 1 & Alas & Rp. 95000 & Rp. 29000 & Rp. 147000 \\
\hline 2 & Bingkai Depan Alas & Rp. 326000 & Rp. 47000 & Rp. 290000 \\
\hline 3 & $\begin{array}{l}\text { Bingkai Samping } \\
\text { Alas }\end{array}$ & Rp. 315000 & Rp. 47000 & Rp. 326000 \\
\hline 4 & Sekat Tengah & Rp. 290000 & Rp. 167000 & Rp. 236000 \\
\hline 5 & Atap & Rp. 110000 & Rp. 11000 & Rp. 111000 \\
\hline 6 & Bingkai Depan Atap & Rp. 387000 & Rp. 47000 & Rp. 326000 \\
\hline 7 & $\begin{array}{l}\text { Bingkai Samping } \\
\text { Atap }\end{array}$ & Rp. 387000 & Rp. 83000 & Rp. 326000 \\
\hline 8 & Dinding Sanping & Rp. 21000 & Rp. 155000 & Rp. 232000 \\
\hline 9 & Rak & Rp. 265000 & Rp. 99000 & Rp. 154000 \\
\hline & Gantungan Hanger & Rp. 376000 & Rp. 231000 & Rp. 268000 \\
\hline 11 & Dinding Belakang & Rp. 110000 & Rp. 77000 & Rp. 110000 \\
\hline & Pintu & Rp. 301000 & Rp. 191000 & Rp. 301000 \\
\hline & Total & Rp. 2.983.000 & Rp. 1.184.000 & Rp. 2.827 .000 \\
\hline
\end{tabular}

Sumber: Pengolahan Data,2019

Berdasarkan tabel 10 dapat ditentukan teknik lot sizing dari jumlah keseluruhan komponen pembentuk lemari adalah teknik EOQ karena memiliki biaya yang sedikit dari teknik LFL dan POQ

\section{g. Analisis Hasil Rencana Kebutuhan Bahan Baku Kayu Per $\left(\mathrm{cm}^{3}\right)$}

Dari data dapat diketahui berapa jumlah bahan baku kayu pembentuk lemari yang harus disediakan setiap periodenya. Untuk komponen alas kebutuhan kayu yang diperoleh selama tiga bulan kedepanya yaitu 2.242.000 $\mathrm{cm}^{3}$, untuk bagian bingkai depan alas dan bingkai samping alas $420.000 \mathrm{~cm}^{3}$, untuk bagian sekat tengah 840.825 $\mathrm{cm}^{3}$, untuk bagian atap $2.242 .000 \mathrm{~cm}^{3}$, untuk bagian bingkai samping atap dan bingkai samping atap 420.000 $\mathrm{cm}^{3}$, untuk bagian dinding samping $1.180 .000 \mathrm{~cm}^{3}$, untuk bagian rak $.700 .000 \mathrm{~cm}^{3}$, untuk gantungan hanger $3.175 \mathrm{~cm}^{3}$, untuk pintu $1.831 .000 \mathrm{~cm}^{3}$.

Jadi total kebutuhan bahan baku kayu untuk tiga bulan kedepanya adalah 11.349.000 atau sama dengan 11,34 $\mathrm{m}^{3}$.

\section{KESIMPULAN}

Berdasarkan hasil perhitungan dan pembahasan pada penelitian ini diperoleh beberapa kesimpulan yaitu, dari penentuan jadwal induk produksi dapat diketahui rencana produksi pembuatan lemari adalah sebesar 4 unit setiap periode (minggu) untuk tiga bulan yang akan datang, dan dari perhitungan MRP dapat diketahui komponen apa saja yang dibutuhkan untuk pembuatan lemari, berapa jumlahnya dan kapan masing-masing komponen itu dibutuhkan. Analisis Material Requirement Planning (MRP) pada UD. AA dilakukan secara manual dikarenakan jumlah itemnya relatif sedikit yang terlihat dalam produksi. Adapun total kebutuhan bahan baku kayu untuk tiga bulan kedepannya adalah sebanyak 11,34 $\mathrm{m}^{3}$. 


\section{DAFTAR PUSTAKA}

Bahagia, Senator Nur, 2003, Sistem Inventori, Laboratorium Perencanaan Optimal Sistem Produksi, Departemen Teknik Industri, ITB

Heizer, J., \& Render, B. (2010). Manajemen operasi. Jakarta: Salemba Empat..

Huseina, A. F., \& Saptadi, S. (2018). PENGENDALIAN PERSEDIAAN RAW MATERIAL METAL DENGAN METODE EOQ Studi Kasus PT DIRGANTARA INDONESIA. Industrial Engineering Online Journal, 7(3).

Kholidasari, I., Setiawati, L., Tartila, T. (2019). The implementation of forecasting method by incorporating human judgment. International Journal on advanced Science Engineering Information Technology, 9 (6), 1982-1988.

Makridakis, S., Wheelwright, S. C., \& Hyndman, R. J. (2008). Forecasting methods and applications. John wiley \& sons.Nasution, A. H., \& Prasetyawan, Y. (2008). Perencanaan dan Pengendalian Produksi, Graha Ilmu.

Rangkuti, F. (2007). Manajemen Persediaan Aplikasi di Bidang Bisnis Edisi 2 Cetakan 5. PT Raja Grafindo Persada. Jakarta. Indonesia.

SUNDARI, S., \& NEGARA, S. W. (2017). Analisis Pengendalian Persediaan Bahan Baku Jenis Gelas $240 \mathrm{~mL}$ dengan Metode EOQ (Economic Order Quantity) di PT. Trijaya Tirta Dharma. Industrika, 1(1).

Trio Mona Purnama. 2002. Perencanaan Sistem Persediaan Bahan Baku Pada CV. Hanifa Perabot

Tersine, R. J. (1994). Principles of Inventory and Materials Management. New Jersey: PTR PrenticeHall. 